УДК 347.195.22:347.195.3

DOI https://doi.org/10.32844/2618-1258.2019.3-1.5

ПАЦЬОРА А.М.

\title{
СОЦІАЛЬНА ВІДПОВІДАЛЬНІСТЬ АКЦІОНЕРНИХ ТОВАРИСТВ: ЮРИДИЧНИЙ АСПЕКТ
}

У статті проводиться загальна характеристика соціальної відповідальності. Проаналізовано останні дослідження й публікації щодо поняття «соціальна відповідальність». Зазначаються особливості соціальної відповідальності з юридичного погляду та з погляду публічного управління. Здійснюється співвідношення понять юридичної й соціальної відповідальності. Розглядаються етапи становлення корпоративної соціальної відповідальності на світовому рівні. Указується про підвищення рівня конкурентоспроможності серед компаній, які встановили корпоративну соціальну відповідальність, порівняно із суб'єктами, що досі не закріпили корпоративну соціальну відповідальність на локальному рівні. Проводиться ознайомлення з вимогами ГД ООН як нормативного документа, який регламентує вимоги до суб'єктів-учасників в аспекті встановлення соціальної відповідальності. Зазначається, в яких саме сферах діяльності встановлення корпоративної соціальної відповідальності є найбільш актуальним. Наголошується на необхідності закріплення такого виду відповідальності відповідно до вимог міжнародної спільноти. Також згадується про заходи, які проведено для закріплення корпоративної соціальної відповідальності в Україні, зокрема Концепцію Національної стратегії соціальної відповідальності бізнесу. Визначається сучасний рівень соціальної відповідальності в Україні. Указується, чому саме вказаний вид відповідальності повинен закріплюватися на прикладі акціонерних товариств. Характеризується соціальна відповідальність акціонерних товариств і шляхи їі реалізації на прикладі таких суб'єктів: ПАТ «Перший Український Міжнародний Банк», ПрАТ «Миронівський Хлібопродукт», ПрАТ «Концерн Хлібпром». У дослідженні також зазначається про взаємозв'язок соціальної відповідальності як відносно нового вектора для протидії та запобігання корупції. Пропонується комплекс заходів, які матимуть на меті впровадження соціальної відповідальності в Україні. Наводяться можливості щодо закріплення соціальної відповідальності на законодавчому рівні. Окремо визначаються останні новини на шляху до встановлення соціальної відповідальності в Україні.

Ключові слова: сочіальна відповідальність, можливість законодавчого закріплення, ГД ООН, протидія корупиії, санкиї за відсутність закріплення.

The article describes the general characteristics of social responsibility. Recent studies and publications on the study of the concept of "social responsibility" have been analyzed. The features of social responsibility from a legal point of view and from the point of view of public administration are noted. There is a correlation between the concepts of legal and social responsibility. The stages of becoming a corporate social responsibility at the global level are considered. This indicates an increase in competitiveness among companies that have established corporate social responsibility, compared to entities that have not yet secured corporate social responsibility at the local level. The requirements of the UN General Directorate, as a normative document, regulate the requirements to the participants-participants in the aspect of establishing social responsibility. The areas of activity of establishing corporate social responsibility are the most relevant. The need to consolidate social responsibility in line with the requirements of the international community is emphasized. It also mentions measures taken to consolidate corporate social responsibility in Ukraine, including the Concept of the National Strategy for Corporate Social Responsibility. The current level of social responsibility in Ukraine is

(C) ПАЦЬОРА А.М. - студентка факультету соціології і права (Національний технічний університет України «Київський політехнічний інститут імені Ігоря Сікорського») 
determined. It is stated why this particular type of responsibility should be fixed on the example of joint-stock companies. The social responsibility of joint-stock companies and the ways of its realization are characterized by the example of the following entities: PJSC "First Ukrainian International Bank", PJSC "Myronovsky Khliboproduct", PJSC "Concern Khlibprom". The study also noted the relationship of social responsibility as a relatively new vector to counteract and prevent corruption. A set of measures is proposed that will be aimed at introducing social responsibility in Ukraine. Opportunities for securing social responsibility at the legislative level are outlined. The latest news on the road to establishing social responsibility in Ukraine is determined separately.

Key words: social responsibility, possibility of legislative fixing, the UN General Assembly, combating corruption, sanctions for lack of consolidation.

Вступ. На сучасному етапі розвитку людства все частіше постає питання діяльності суспільства як цілісного організму в тому аспекті, що передбачає здійснення людьми діяльності, яка б ураховувала інтереси прийдешніх поколінь. Сьогодні такий напрям розвитку називають сталим розвитком. На нашу думку, щоб реалізувати зазначену тезу, необхідно закріплення й дотримання суспільством певного виду відповідальності, зокрема соціальної або, як іiї ще називають у рамках діяльності компаній, корпоративної соціальної відповідальності (далі - КСВ). Зупинимося на перспективі законодавчого закріплення корпоративної соціальної відповідальності для акціонерних товариств.

Узагалі питанню соціальної відповідальності не тільки акціонерних товариств, а й бізнесу загалом присвячена досить значна кількість наукових публікацій. Зокрема, праці Г. Боуена, К. Девіса спрямовані на встановлення концепцій корпоративної соціальної відповідальності у світі. Дослідження, яке здійснювала Л. Петрашко, розглядає корпоративну соціальну відповідальність української бізнес-практики поряд із міжнародними стандартами та приписами; публікація Н. Косар, В. Пилипенко, Н. Кузьо спрямована на характеристику принципів політики соціальної відповідальності суб’єктів господарювання в Україні.

Дослідження, які проводилися, з метою вивчення поняття «соціальна відповідальність» у більшості випадків стосуються розвитку такого виду відповідальності в галузі публічного управління, однак при цьому можливість запровадження соціальної відповідальності не розглядається з юридичного погляду. Перспективи запровадження корпоративної соціальної відповідальності для господарських товариств і насамперед для акціонерних товариств на законодавчому рівні майже відсутні.

Постановка завдання. Метою статті є виявлення впливу соціальної відповідальності акціонерних товариств і перспективи ії закріплення на законодавчому рівні.

Результати дослідження. У теорії держави і права юридична відповідальність $є$ видом соціальної відповідальності й за своєю правовою сутністю характеризується наявністю санкцій, які, у свою чергу, офіційно закріплені на законодавчому рівні. Соціальна та юридична відповідальність - поняття не однакові за своїм змістом. Щоб говорити про переваги корпоративної соціальної відповідальності, варто визначити іiі межі й особливості порівняно з юридичною відповідальністю.

Як ми вже зазначали, юридичній відповідальності властивий нормативний характер закріплення й наявність певного виду санкції, який настає за наявності складу правопорушення. Юридична відповідальність розподіляється на підвиди, одними з яких є адміністративна, кримінальна, цивільна, дисциплінарна відповідальність відповідно до вчиненого виду порушення.

У свою чергу, соціальна відповідальність розглядається як «загальне» щодо явища «відповідальність» загалом. Такий тип відповідальності більше орієнтований на принципи етики й моралі та не має офіційно визначених і закріплених санкцій, оскільки призначається недержавними структурами. Однак вищезазначені фактори не означають меншу важливість соціальної відповідальності поряд із юридичною. $1950 \mathrm{p}$.

На міжнародній арені встановлення КСВ й подальший іiі розвиток бере свій початок ще 3

Так, зокрема, провідне місце посідає наукова праця Г. Боуена «Соціальна відповідальність бізнесмена», згідно з якою соціальна відповідальність бізнесмена полягає в реалізації політики, прийнятті рішень або додержанні лінії поведінки, які були б бажані для цілей і цінностей суспільства [5]. Згодом К. Девіс розглядав суб'єкт господарювання як спільне підприємство, яке 
відповідає за задоволення не тільки економічних, а й соціальних, психологічних, політичних та інших очікувань суспільства [5]. Як бачимо, основний мотив тез Г. Боуена, К. Девіса полягає в тому, що діяльність бізнесу (людини як самостійного бізнесмена та як об'єднання людей у формі господарських товариств) повинна мати на меті не лише реалізацію власних комерційних завдань, а й вищу мету, якою виступатиме життєздатна діяльність суспільства загалом. Досягнення такої «вищої» мети можливе лише за умови ведення бізнесу відповідно до встановлених норм законодавства, що означає насамперед бути офіційно зареєстрованим суб'єктом ведення господарської діяльності та здатним надати фінансову-господарську звітність, яка б відображала реальні результати ведення комерційної діяльності.

Явище КСВ у світі не $є$ новим i, більше того, $є$ фактором, який орієнтує на те, що компанія, яка хоче займати вигідне становище на ринку, повинна дотримуватися такого виду відповідальності. Так, КСВ стає передумовою для введення дійсно конкурентоспроможного середовища, тому що ведення такої «правильної» соціальної відповідальної діяльності буде заохочувати нових потенційних клієнтів, інвесторів і стане певним прикладом заохочення для інших компаній конкурувати на одному соціально відповідальному рівні.

Зокрема, дослідження Walker Information дали змогу встановити пряму залежність між соціальною цінністю компанії, іiі репутацією та вірністю споживачів іiї бренду. Зокрема, визначено, що соціальні показники впливають на репутацію компанії вдвічі більше, ніж економічні. Загальна прибутковість корпорацій, що мають високі фінансові та соціальні показники, за останні 15 років зросла на 43\%, а лише фінансово успішних компаній, які не задіюють концепцію соціальної відповідальності, - на 19\%. Прибутковість продажу соціально активних компаній на $3 \%$ вища, прибутковість активів - на 4\% вища, а прибутковість капіталу на акції - на 10\% вища, ніж у соціально неактивних компаній [3].

У сфері КСВ світовою спільнотою прийнято рішення про ухвалення 26 липня 2000 р. в рамках ініціативи ООН Глобального договору ООН (далі - ГД ООН), який спрямовано на сприяння соціальній відповідальності бізнесу та надання звітів про здійснення такої політики. Станом на вересень 2019 р. до ГД ООН приєдналося 9531 компаній із 162 країн світу [8]. ГД ООН базується на десятьох принципах, основною метою яких є забезпечення діяльності комерційних компаній у сферах захисту прав людини, принципів праці, екологічної відповідальності й протидії корупції. Форма участі - добровільна. Санкції за недотримання принципів, установлених ГД $\mathrm{OOH}$, не передбачено.

Міжнародна спільнота визначає необхідність розвитку в Україні сфери соціальної відповідальності з огляду на позиціонування України в глобальному бізнес-середовищі, географічну належність до регіону зі стійкими традиціями у сфері КСВ - Свропейського Союзу, підтримку глобальних ініціатив: ГД ООН, Керівництва для мультинаціональних підприємств Організації економічного співробітництва та розвитку (ОЕСР), Всесвітньої ради бізнесу зі сталого розвитку (WBCSD), Принципів ОOH із соціальної відповідальності інвесторів (PRI), Глобальної ініціативи зі звітності (GRI), Міжнародного стандарту ISO 26000 «Керівництво щодо соціальної відповідальності» [4]. Також до перерахованих вище ознак можна зарахувати стрімкий розвиток у галузі інформатизації суспільних відносин, електронного урядування.

Виходячи із згаданих факторів, в Україні практика встановлення соціальної відповідальності існує. Наприклад, у 2010-2011рр. тривало розроблення Концепції Національної стратегії соціальної відповідальності бізнесу при Комітеті з питань промислової й регуляторної політики та підприємництва Верховної Ради України.

За загальним визначенням, яке міститься в згаданій стратегії, соціальна відповідальність це відповідальність компанії за вплив ііі рішень і дій на суспільство, навколишне середовище шляхом прозорої та етичної поведінки, яка сприяє сталому розвитку, у т. ч. здоров'ю та добробуту суспільства; враховує очікування зацікавлених сторін; відповідає чинному законодавству й міжнародним нормам поведінки та інтегрована в діяльність організації і практикується в їі відносинах [6]. КСВ - це явище, яке потребує тісного взаємозв'язку з працюючим персоналом, керівництвом, державою та суспільством.

Одними з основних завдань Стратегії визначаються:

1. розвиток соціально відповідального бізнесу, підвищення рівня конкурентоспроможності з метою визнання українського бізнесу на світовій арені як соціально відповідального, його полегшеної інтеграції в міжнародні ринки;

2. запровадження єдиних підходів до розуміння соціальної відповідальності бізнесу в Україні всіма групами заінтересованих осіб; 
3. розвиток системи нефінансового звітування з метою більшої поінформованості суспільства щодо різних аспектів КСВ;

4. створення передумов для гарантій забезпечення прав людини, етичного виховання та освіти членів суспільства [6].

Стратегія визначає більш загальні, основоположні завдання, на основі яких має будуватися соціальна відповідальність окремих суб'єктів. Зокрема, передбачається й запровадження єдиного підходу розуміння соціальної відповідальності й надання нефінансової звітності, тобто звітності, яка спрямована саме на реалізацію КСВ. Однак згадана Стратегія мала бути реалізована ще до 2015 р., а згодом, із подальшими змінами, до 2020 р. 3 повним текстом можна ознайомитися на сайті соціально відповідального бізнесу, який здійснює моніторинг соціальної відповідальності в Україні[7].

На нашу думку, КСВ може поширюватися між суб'єктами господарювання на прикладі саме акціонерних товариств. По-перше, відповідно до ч. 1 ст. 14 Закону України «Про акціонерні товариства», мінімальний розмір статутного капіталу акціонерного товариства становить 1250 мінімальних заробітних плат, виходячи з розміру мінімальної заробітної плати, що діє на момент створення (реєстрації) акціонерного товариства [1]. Сьогодні, згідно зі ст. 8 Закону України «Про державний бюджет України на 2019 рік», мінімальна заробітна плата у місячному розмірі становить 4173 грн. [2]. Тобто під час створення акціонерного товариства у 2019 р. розмір мінімального статутного капіталу мав бути 5216260 грн. Така сума насамперед указує на те, що будь-яке акціонерне товариство дійсно має намір реально здійснювати свою діяльність і бути готовим відповідати за ії реалізацію перед суспільством. По-друге, в організаційно-правовій формі акціонерного товариства створюються банки, біржі, холдингові компанії (державна холдингова компанія) та інші великі суб'єкти (наприклад, суб'єкти паливно-енергетичного комплексу), які посідають важливе місце в національній економіці країни. По-третє, акціонерні товариства $є$ одним із найпопулярніших видів господарських товариств. Аналізуючи зазначені складники, можна ще раз сказати, що акціонерні товариства повинні запровадити соціальну відповідальність як необхідний приклад для інших суб'єктів ведення соціально-відповідальної діяльності.

Натепер уже існують акціонерні товариства, які встановили соціальну відповідальність. Зокрема, проведемо аналіз КСВ таких суб'єктів: ПАТ «Перший Український Міжнародний Банк», ПрАТ «Миронівський Хлібопродукт», ПрАТ «Концерн Хлібпром».

ПАТ «Перший Український Міжнародний Банк» $є$ активним представником упровадженої соціальної відповідальності. Зокрема, з квітня 2013 р. ПАТ «ПУМБ» приєднався до ГД ООН і з 2015 р. надає звіти про свою діяльність, так як це передбачають умови ГД ООН, більше того, зазначені звіти перебувають у повному відкритому доступі, так що кожний охочий може з ними ознайомитися. Звіт являє собою інформацію про реалізацію основних принципів ГД ООН, а саме: принципів прав людини, принципів трудових відносин, екологічних принципів і принципу протидії корупції. Так, наприклад, реалізація екологічних принципів здійснюється завдяки економному витрачанню енергоресурсів і паперу, використанню процедури електронного документообігу. Протидія корупції впроваджується через чинну антикорупційну програму ПУМБ; процедуру з вибору підрядників, що забезпечує прозорість і відкритість проведення закупівель; політику антимонопольного комплаєнсу, основною метою якої $є$ недопущення виникнення порушень у сфері конкурентного права з боку відповідальних підрозділів банку тощо [9]. Охорона трудових відносин реалізується через дію колективного договору, у якому містяться положення щодо умов та оплати праці, соціальних пільг і гарантій. Відповідно до принципу захисту прав людини, у ПАТ «ПУМБ» діє кодекс корпоративної етики ПУМБ. Як бачимо, ПАТ «ПУМБ» своїм реальним прикладом показує, що КСВ - це спосіб довести взаємовплив між персоналом і суспільством, здійснювати свою діяльність і бути готовим відповісти за неї.

Аналізуючи КСВ ПрАТ «Концерн Хлібпром», варто відзначити ключову тезу товариства щодо необхідності соціальної відповідальності: «... запорука успішної компанії - це не тільки фінансова складова, а й високі стандарти ведення бізнесу на всіх його ланках. Досягнення позитивного довготермінового результату є можливим при урахуванні інтересів як безпосередньо споживачів, так і працівників, партнерів, інвесторів, акціонерів, місцевих громад та інших заінтересованих сторін, які мають взаємодію з Компанією» [10]. Саме такого правила й повинні дотримуватися інші суб'єкти господарювання у своїй діяльності. 3 огляду на зміст Кодексу корпоративного управління, ключовими напрямами роботи для компанії в секторі КСВ є: 1) відповідальність перед споживачами за якість продукції; 2) відповідальність перед партнерами за чесне 
та добросовісне партнерство на відкритих засадах; 3) відповідальність перед суспільством за вплив на навколишнє середовище [10].

Ще одним представником з установленою соціальною відповідальністю $є$ ПрАТ «Миронівський Хлібопродукт(МХП)». Так, пріоритетами політики КСВ $\epsilon: 1)$ взаємовигідне партнерство із зацікавленими сторонами; 2) поліпшення добробуту й рівня життя населення України; 3) захист довкілля та поліпшення енергоефективності підприємств групи МХП [11]. Згідно з кодексом етичної поведінки, корпоративна соціальна відповідальність - невід’ємна частина бізнесу, яка базується на дотриманні цілей сталого розвитку, дотриманні політики протидії корупції та зв'язку із засобами масової інформації (далі - ЗМІ) [12]. У кодексі етичної поведінки МХП також зазначена актуальна теза, що ЗМІ виступають як посередники як компанією і громадськістю.

Зараз в епоху інформаційного розвитку ЗМІ відіграють одну з вирішальних ролей щодо доведення інформації до споживачів. Важливим фактором є те, щоб компанії, акціонерні товариства в тому числі, встановили тісний зв'язок зі ЗМІ. За наявністю такого зв'язку основні ідеї й принципи соціальної відповідальності будуть швидше доходити до відома споживачів, а це,у свою чергу, сприятиме підвищенню рівня правосвідомості громадян.

Як згадано раніше, одним із принципів ГД ООН є принцип протидії корупції. У зв'язку з тим що в Україні існує досить негативна тенденція щодо вчинення корупційних злочинів, здійснення заходів, які мають на меті протидію та запобігання їм, $є$ одними з ключових напрямів антикорупційної політики. На нашу думку, найпростішим прикладом реалізації одного 3 напрямів КСВ можуть слугувати запроваджені антикорупційні програми на рівні суб'єктів господарювання. Це можуть бути різного роду лекційні заняття щодо роз'яснення Закону України «Про запобігання корупції», доведення до відома працівників практичних випадків щодо запобігання конфлікту інтересів і врегулювання його, а також особливості притягнення до відповідальності за вчинення корупційних правопорушень і правопорушень, пов'язаних із корупцією.

Також до зазначеної Антикорупційної програми можна зарахувати політику комплаєнсу, основними напрямами якої є протидія легалізації доходів, отриманих злочинним шляхом; протидія корупції, шахрайству та фінансуванню тероризму; розроблення документів і процедур, що забезпечують відповідність діяльності компанії чинному законодавству; усунення конфлікту інтересів; захист даних; антимонопольний комплаєнс [13].

Однією з останніх новин на шляху до встановлення КСВ в Україні стала презентація Декларації державних компаній про слідування Цілям Сталого Розвитку ГД ООН разом із компаніями Укрзалізниця та Енергоатом. Декларація відкрита до приєднання всіх зацікавлених сторін і має на меті:

1) створити й узгодити конкретний план дій для покращення системи управління корпоративною соціальною відповідальністю в державних підприємствах з урахуванням їх специфіки й обмежень діяльності;

2) підвищити прозорість і відкритість бізнесу, впровадити кращі міжнародні практики нефінансової звітності;

3) сприяти поширенню й упровадженню практики соціальної відповідальності та врахування суспільних інтересів у повсякденній діяльності підприємств по всій території України [8].

Одна з особливостей соціальної відповідальності полягає в тому, що вона не має законодавчого характеру закріплення порівняно з юридичною відповідальністю, крім того, умови ГД $\mathrm{OOH}$ не передбачають санкцію за порушення його вимог чи санкцій за невстановлення КСВ, а тому постає питання, яким способом можна зобов'язати господарські товариства впровадити у свою діяльність цілі КСВ? Однією з альтернатив може слугувати приклад запровадження норми, яка стосується КСВ, у Законі України «Про акціонерні товариства» такого змісту: «Товариством повинна передбачатися соціальна відповідальність, яка реалізується через форму подання нефінансової звітності, а також ужиття комплексу заходів, спрямованих на запобігання та протидії корупції». Наявність у запропонованій статті згадування заходів боротьби з корупцією безпосередньо пов'язано з принципом протидії корупції ГД ООН.

Проте варто зазначити про відсутність санкції в разі недотримання вимог щодо запровадження КСВ. Насамперед це зумовлено тим, що положення ГД ООН не встановлюють відповідну санкцію, а тому закріплення іїі в Україні потребує детального вивчення, особливо в частині виду й розміру санкції, яка буде встановлена, що, у свою чергу, може призвести до низки непорозумінь з боку представників бізнесу. Як уже неодноразово згадано, наявність закріпленої КСВ в акціонерних товариствах має низку переваг, дотримання яких зумовить покращення позиції такого товариства як суб’єкта економічних і юридичних відносин не тільки на національному, а й міжнародному рівнях. 
Висновки. Отже, аналізуючи все вищезазначене, можемо резюмувати таке:

1. Соціальна відповідальність - це готовність товариства нести відповідальність за діяльність компанії перед суспільством і навколишнім середовищем, ураховувати інтереси заінтересованих сторін під час прийняття важливих рішень, сприяти захисту й добробуту населення.

2. Соціальна відповідальність не є тим загальним уявленням юридичної відповідальності, тобто не має нормативного характеру закріплення, не передбачає санкцій за її недотримання й не передбачає ознак складу правопорушення. Фактично зараз КСВ - це абстрактне поняття, яке тільки набирає популярності в Україні. Інформатизація суспільних відносин, упровадження електронного урядування, збільшення ролі 3МІ - усе це поволі стає основою для соціальної відповідальності й, можливо, вже в близькому майбутньому КСВ буде реально існувати на законодавчому рівні та, більше того, існуватимуть санкції за ії недотримання.

3. Значний вплив на розвиток КСВ можуть здійснити акціонерні товариства, які своїм прикладом намагатимуться донести до інших суб'єктів господарювання переваги введення соціальної відповідальності. Зокрема, до таких переваг можна зарахувати підвищення рівня конкурентоспроможності порівняно з компаніями без установленої КСВ; підвищення рівня ділової репутації компанії; взаємодія працівників і керівництва як єдиного організму; проведення політики співпраці зі ЗМІ з метою поширення принципів КСВ; захист навколишнього середовища.

4. Для початку задля впровадження КСВ пропонуємо здійснення таких заходів: закріплення терміна «соціальна відповідальність», який матиме на меті визначення єдиного підходу для однакового розуміння явища КСВ серед суспільства; виявлення найбільш ефективних шляхів реалізації соціальної відповідальності (на прикладі діяльності суб'єктів, зокрема й акціонерних товариств, з уже встановленою КСВ); установлення обов'язку подання звіту про заходи соціальної відповідальності та розміщення такого звіту у відкритому доступі; запровадження антикорупційних програм.

\section{Список використаних джерел:}

1. Про акціонерні товариства : Закон України від 17 вересня 2008 року № 514-VI. URL: https://zakon.rada.gov.ua/laws/show/514-17?find=1\&text=1250\#w11.

2. Про державний бюджет України на 2019 рік : Закон України від 23 листопада 2018 року № 2629-VIII. URL: https://zakon.rada.gov.ua/laws/show/2629-19.

3. Косар Н.М., Пилипенко В.М., Кузьо Н.Є. Корпоративна соціальна відповідальність бізнесу в Україні. Наиіональний університет «Львівська політехніка». 2014. URL: http://ena.lp.edu. ua:8080/bitstream/ntb/29391/1/027_176_183.pdf.

4. Петрашко Л. Корпоративна соціальна відповідальність в українській бізнес-практиці. Міжнародна економічна політика. 2011. Вип. 1-2. URL: http://nbuv.gov.ua/UJRN/Mep_2011_1-2_7.

5. Шандова Н.В., Жосан Г.В. Соціальна відповідальність: навчальний посібник. Херсон : Вид-во ПП Вишемирський В.С., 2016. URL: https://pidruchniki.com/83403/sotsiologiya/ kontseptsiyi_sotsialnoyi_vidpovidalnosti.

6. Концепція Національної стратегії соціально відповідального бізнесу в Україні. URL: http://svb.ua/sites/default/files/201108_koncepciya_nacionalnoyi_strategiyi_svb.pdf.

7. Офіційний сайт «Соціально відповідальний бізнес». URL: http://svb.ua/national-csrstrategy.

8. Офіційний сайт мережі Глобального договору ООН в Україні. URL: https://ru.wikipedia. org/wiki/Глобальный_договор_ООН.

9. Звіт про прогрес ПУМББ за 2018 p. URL: https://about.pumb.ua/content/cmsfile/ua/\%D1\%8 $1 \% \mathrm{D} 1 \% 82 \% \mathrm{D} 0 \% \mathrm{~B} 0 \% \mathrm{D} 0 \% \mathrm{BB} \% \mathrm{D} 0 \% \mathrm{~B} 8 \% \mathrm{D} 0 \% \mathrm{~B} 9 \% 20 \% \mathrm{D} 1 \% 80 \% \mathrm{D} 0 \% \mathrm{BE} \% \mathrm{D} 0 \% \mathrm{~B} 7 \% \mathrm{D} 0 \% \mathrm{~B} 2 \% \mathrm{D} 0$ $\%$ B8\%D1\%82\%D0\%BE\%D0\%BA_fuib\%20cop\%202018_ua.pdf?v=636898116041626278.

10. Офіційний сайт ПрАТ «Концерн Хлібпром». URL: https://hlibprom.com.ua/static/csr/.

11. Політика корпоративної соціальної відповідальності ПрАТ «Миронівський Хлібопродукт». URL: https://www.mhp.com.ua/library/file/kso-fin-ukr-2017.pdf.

12. Кодекс етичної поведінки ПрАТ «Миронівський Хлібопродукт». URL: https://www. mhp.com.ua/library/file/mkhp-kodeks-etichnoi-povedinki-fin-04-10-2018_1.pdf.

13. Сидоренко Д. Комплаєнс: why do we need it? Юридична газета online. 2018. Вип. 1920. C. 621-622. URL: http://yur-gazeta.com/publications/practice/inshe/komplaens-why-do-we-needit.html. 